\title{
Kenya's Leadership Response to Covid-19 Pandemic and Possible Interventions between March and June 2020
}

\author{
${ }^{1}$ Knollyne Oindih Gai and ${ }^{2}$ Prof. Musa Nyakora, PhD \\ ${ }^{1} \mathrm{PhD}$ in Leadership Scholar, Adventist University of Africa, Kenya \\ ${ }^{2} \mathrm{MA}$ and $\mathrm{PhD}$ in Leadership Program Leader, Adventist University of Africa, Kenya
}

Correspondence: oindihk@aua.ac.ke, nyakoram@aua.ac.ke

\begin{abstract}
Kenya is one of those countries in the world suffering from the deadly Corona virus and its economy is greatly affected. There is therefore a need for the Kenyan government to put measures in place to break the chain of spreading the virus by enforcing nationwide curfew, boarder lockdown of the most affected counties and stay and work from home measures. The Ministry of health alongside its stakeholders had to quickly set up various mechanisms to counter the disease. The government took drastic steps to curb the spread of the pandemic by closing down learning institutions, entertainment joints, eateries and public gathering including funerals. Church services and weddings were temporarily banned too. This was to break the chain and reduce the spread of the virus and if possible completely eliminate the Covid-19 in the country. Due to the urgency of the matter, leaders needed to embrace new ways of doing things and have a vision clearly spelt and well understood approach. On the other hand, leaders in charge of communication needed to verify their facts and not be too quick to call for press conferences to ensure that channels of communications were open to all in order to avoid speculations that results in lack of trust if things are not done in a transparent way.
\end{abstract}

Key words: Curfew, Covid-19, Break chain, Lockdown, pathogenic

\section{Introduction}

Literature on Covid 19 includes one published by de Wilde (2020) on the background of this deadly virus in which the author contends that Human Coronaviruses (HCoVs) have long been considered inconsequential pathogens, causing the "common cold" in otherwise healthy people. It is something that many nations have learned to live with since it has existed for many years. Paules et al. (2020), while giving the background of the Corona Virus history, states that in the 21st century, two highly pathogenic HCoVs-Severe Acute Respiratory Syndrome Coronavirus (SARS-CoV) and Middle East Respiratory Syndrome Coronavirus (MERS-CoV)emerged from animal reservoirs to cause global epidemics with alarming morbidity and mortality. Before this time, these pathogens were in existence but they were not a global nightmare that is causing heads to roll like they are doing now all over the globe.
Various authors like Paules et al., (2020), Song et al (2019) state that until recently, HCoVs received relatively little attention due to their mild phenotypes in humans. Things changed in 2002, when cases of severe atypical pneumonia were described in Guangdong Province, China, causing a worldwide concerns as the disease spread via international travel to more than 2 dozen countries. Despite the spread of the virus to various countries surrounding China, the virus was not yet a global threat. Later on, the disease became known as Severe Acute Respiratory Syndrome (SARS) and a Beta-HCoV, named SARS-CoV and was identified as the causative agent. According to Song et al (2019), because early cases shared a history of humananimal contact at live game markets, zoonotic transmission of the virus was strongly suspected.

According to Wang and Qui et al. (2020), the International Committee on Taxonomy of Viruses 
(ICTV) named the virus SARS-CoV-2 and the disease COVID-19. Prior to this time, the World Health Organization (WHO) had not given a proper name to the disease and had not declared it a pandemic. Lai and Shih et al (2020) indicate that on 30 January 2020, the WHO declared COVID-19 as the sixth public health emergency of international concern. This was the first time the deadly flu got its official name of Covid-19. The authors continue to argue that SARS-CoV-2 is closely related to two Batderived severe acute respiratory syndrome-like Coronaviruses, Bat-SL-CoVZC45 and Bat-SLCoVZXC21. Up to now, there has never been a cure or vaccine to the virus.

According to A Comprehensive Guide on Mental Health \& Psychosocial Support (2020), the following are the best ways to protect oneself from being exposed to the virus that causes COVID-19: (1) Staying home as much as possible and avoiding close contact with others whether one is sick or not. This way, the chain of transmission is broken and therefore reducing the spread of the virus from one person to others. (2) Wearing a cloth that covers nose and mouth in public settings. This is known as face mask. (3) Cleaning and disinfecting frequently touched surfaces. (4) Washing hands often with soap and water for at least 20 seconds or using an alcohol based hand sanitizer that contains at least $60 \%$ alcohol. (5) Avoiding overcrowded places. Should one find himself/herself in a public place, practicing social distancing is required.

Kenya confirmed its first coronavirus case at Ongata Rongai town in Kajiado North Constituency, Kajiado County. A Statement-on-Confirmed-COVID-19-Case (2020) stated that the first victim was tested on the $12^{\text {th }}$ of March 2020 . This victim was a Kenyan citizen returning home from a trip in the United States via United Kingdom. Two weeks later, the number rose to 31 and thereafter, the Minster of Health announced that Kenya lost its first covid-19 patient.

Amid fears of a major outbreak in the country, the country's president, His Excellency, Uhuru Kenyatta announced a series of sweeping measures to slow or hopefully completely break the chain of COVID19 in the country. This announcement was made in a Presidential press conference (2020). On the same press release to the various media houses in Kenya, the government put in place measures to break the chain of the virus. The measures included shutting the borders and suspending most air travels, except cargo flights. Kenya also asked government institutions, businesses and companies to allow staff to work from home, with the exception of employees working in critical or essential services. Closing down learning institutions was also a measure put in place by the president to help cut the chain of coronavirus as all learning institutions both private and public were shut down and the students were required to return to their homes.

Due to the background of this study, the COVID-19 pandemic unquestionably presents an era-defining challenge to public health and the global economy. Its political consequences, both short-term and long-term are less understood. The global outbreak has had the potential to wreak havoc in fragile states and trigger widespread unrest and severely test international crisis management systems (Crisis Group Special Briefing 2020).

Because of the rise of the Covid-19 victims, the government decided to close not only the learning institutions but also the entertainment joints, eateries and public gatherings including funerals. Church services and wedding ceremonies were temporarily banned on $22^{\text {nd }}$ March, 2020 when some new cases were tested. Soon after, the country was slapped with a curfew whereby from 7 pm to 5 am anyone found outside his/her house would be fined two thousand Kenya Shillings which was to be paid on the spot.

Since no one could predict when and where the virus would hit hardest and whether the pandemic's consequences would be entirely or uniformly negative for peace and security, the president announced a containment of a few counties including Nairobi, Mombasa, Kwale, Kilifi, Kajiado, Machakos, Thika and Kiambu on April 6, 2020 (Crisis Group 2020). The containment stated that there would be no movement in and out of the counties. This was a very strategic move by the government because the rest of the counties still did not have any existing cases of Covid-19 patients. If the containment was not done, the country would have been faced with a dangerous scenario. It is important to note that, movement within the counties was allowed, as long as precautionary measures were taken such as wearing of face masks, washing hands with soap and flowing water and using sanitizers during this containment period.

The duration of the boarder lockdown started on the $6^{\text {th }}$ March 2020 and was supposed to run for 21 days. At the expiration of the date, on $25^{\text {th }}$ April, 
2020, an extension of the lockdown was announced by the government. The other measures the government took to reduce or break the chain of Covid-19 include the following: (1) Suspending all public gatherings, face to face meetings and events. (2) All public transport providers were to provide hand sanitizers to clients and regular cleaning of the vehicles. (3) Visits to prisons were suspended for 30 days. When the time elapsed, more extension periods were prescribed. (4) The use of social media to spread misinformation was stopped and all official communications were to circulate with a government logo.

\section{Measures Taken to Mitigate Covid-19 in Kenya}

Reviewing the 2014 Ebola outbreak in Guinea, Liberia and Sierra Leone, Crisis Group (2015) noted that the virus initially spread unchecked not only because of the weakness of epidemiological monitoring and inadequate health system capacity and response but also because people were skeptical of what their governments were saying or asking them to do. As the result, the cases continued to increase across the countries. This is a sign that negligence can pave ways for the spread of the disease.

While doing their parts to mitigate the Covid-19, Kenyan leaders have been accused of corruption. The leaders faced graft charges but they were never convicted of their crimes. The latest corruption charges were against the Ministry of Health. According to Ruvagu (2020), organizations have contributed aid worth more than \$2 billion to help Kenya's in its fight against COVID-19. But much of the aid has gone missing, prompting President Uhuru Kenyatta to order an investigation into who might have taken it. Money and medical supplies were donated by such groups as the World Bank, the International Monetary Fund and the Jack Ma Foundation. With such discrepancies in the government, many citizens were in doubt of the existence of the covid-19.

Gathara (2020) gives a clear picture of the situation in Kenya during the crisis while writing to The Washington Post on $7^{\text {th }}$ May, 2020. He states in his article that Kenya's Cabinet Secretary for Health, Mutahi Kagwe was an unhappy man as a week after the government tentatively allowed restaurants to reopen from 5 a.m. to 4 p.m., he seemed surprised that Kenyans are actually patronizing these establishments and having beer with sausages.
Simply put, since the bars were closed but the eateries were allowed to serve alcoholic drinks with food, Kenyans would order a sausage or any other cheap foods in order to be served with drinks. This is a clear sign of defiance due to poor communication. The author continues to state; as the state sought to position itself as a father figure, its own conduct has been questionable, to say the least. Its agents have engaged in the illegal demolition while urging citizens to stay indoors. At the end of the day, the money intended to be used to help reduce or stop the deadly virus have been rerouted to other duties or divided among the top leaders and a few loyal followers of the said leaders.

Apart from the strategies mentioned above, the government of Kenya had also gone an extra mile to assure Kenyans of their safety even in their lockdown. During the lockdown, many citizens preferred to have their food delivered at their doorsteps. The food handlers were subjected to test so they would not be carriers of the virus to people's homes. The Government worked out a plan to have all food handlers tested for Covid-19 despite the challenge of some essential components of test kits missing from a statement released by Dr. Rashid Aman, the Chief Administrative Secretary (2020).

Rashid (2020) continued to say, "We are asking for patience and cooperation with the management of these facilities and encourage the food suppliers to arrange for private testing of their staff in consultation with the Ministry of Health." This was a strategic move considering that many Kenyans chose to stay home and have food supplies delivered to them. The Government further issued initial guidelines for partial reopening of eateries and restaurants in line with the directives issued by President Uhuru Kenyatta.

On $27^{\text {th }}$ April, 2020, the Cabinet Secretary (CS) in the Ministry of Health, Mutahi Kagwe inaugurated the National Advisory Committee to oversee proper supply and utilization of Blood and Blood Products. The multi-disciplinary Committee that was to be chaired by Mr. Abbas Gullet, a Kenyan humanitarian worker, who since 2001, has been Secretary General of the Kenya Red Cross Society, would provide leadership in assisting, identifying, designing and implementing cost-effective blood utilization management initiatives for the optimization of patient care. In his words, the minister says the committee will; "further develop a system to resolve the perennial shortage of blood and blood products 
in Kenya and to have institutionalized blood management in support of county governments' participation." The reason why the ministry of health involved and inaugurated the blood management committee was as a result of the unclear circumstances around covid-19 pandemic. In order to be adequately prepared for the unexpected, the government of Kenya took all the necessary precautionary measures including having enough blood in the banks in case the infected patients needed to be transfused.

The committee was also expected to draft a legislative and regulatory report setting out rules, regulations, orders and other measures required to give into effect the proposed reforms, including a Bill of Parliament on the proposed Kenya National Blood Transfusion Service. Since from the beginning of the pandemic it was not clear, the Government leaders became visionary and made all the necessary measures to tackle the pandemic. Looking beyond the Covid-19 pandemic, visionary leadership is necessary and relevant at all times but more especially during uncertain period of covid-19.

Today, strategic leaders work in an ever increasing Volatility, Uncertainty, Complexity and Ambiguity, (VUCA) environment. VUCA is an acronym, first used in 1987 and based on the leadership theories of Warren Bennis and Burt Nanus (1985). It was the response of the US Army War College to the collapse of the USSR in the early 1990s. Suddenly, there was no longer the enemy, resulting in new ways of seeing and reacting. It is a strategy for steady leadership in an unsteady world. VUCA describes perfectly what is happening in the global business world today with the Covid-19 pandemic. Kenyan leaders were not left behind in this unclear situation. The government tried everything possible to completely eradicate the Corona Virus in the country despite the fact that the Covid-19 trends were unpredictable.

\section{Financial Management Challenges}

Financial management is one of key aspects for leadership. Despite the series of interventions taken, Kenyan leaders have been hit with scandals since the World Bank brought money into the country for the covid-19 pandemic. Nyamori (2020) while writing an article in the Standard newspaper tries to answer or analyze where the donated money to Kenya was spent. The newspaper reported that the state had spent Shs. 1.3 billion in the fight against the deadly virus. In the breakdown, the leaders mandated to take care of Kenyans during this pandemic period had spent, Shs. 70 million on communication, Shs. 42 million on hiring ambulances, Shs. 12 million on house health workers and the most memorable is the Shs. 4 million for tea and snacks. Instead of using the money for the intended purpose, some people believe that a few leaders fattened their bank accounts at the expense of the common man. During the initial stages of the virus in the country, there were Kenyans who were quarantined at their expenses and were not able to pay for their cost and instead of the government intervening, they were being held hostage for not being able to pay their dues, yet the government had received billions to combat the deadly virus. Abdi (2020) wrote an ordeal of one Kenyan who lost her job in Dubai and was quarantined on returning to Kenya. While speculations against leaders' misappropriation of funds for Covid- 19 cannot are proven wrong or right, transparency on the part of leaders could be the best approach in addressing the issue.

\section{Conclusions and Recommendations}

Covid-19 infection is a deadly disease with low to moderate mortality rate in many countries around the world. Currently, there is no standard treatment but there are various supportive treatments available for the patients. So far, many countries are struggling to come up with the best vaccine. As the world watches and waits for the vaccine, individuals can take control of their own lives by following the laid down guidelines on prevention and possible care in case one contracts the deadly virus. Therefore, Kenyan citizens need to protect themselves by following keenly the guidelines mentioned above.

Corona virus is no longer a new concept. People have suffered from it. While some were unlucky to live to tell their experiences, many recovered to share their experiences. Kenyans need to recognize the reality of the virus and take care of themselves by observing the said measures to break the chain of the spread of this deadly virus. At the same time, the Kenyan leadership needs to do their part by constantly providing clear communication on the progress and help the citizens cope with the situation. The communication should be done on a regular basis, giving even the financial reports in order to avoid speculations that results in lack of trust if things are not done in a transparent way. It is 
the responsibility of both the citizens and the leaders to help stop the spread of the virus.

The managerial concept of Volatility, Uncertainty, Complexity, and Ambiguity (VUCA) has been used to lead and manage in unclear situation like the one currently being experienced across the globe. Even though leaders apply this concept to manage the current pandemic, there is always room to improve the leadership and management styles. Thus, there is a need to reverse the order and have a new era requiring new ways of leading. On top of the VUCA principle, the authors of this paper suggest an alternative leadership principle for crisis management with the same VUCA acronym as follows: (1) Vision: The leader needs to have a clear Vision. (2) Understanding: The leader must listen for understanding so that they can respond to issues that need attention. (3) Clarity: The leaders need to see clearly through the fog and respond to what matters. (4) Agility: The leader needs to communicate and change/respond quickly/on time.

When leaders use such a recommended leadership principle during crisis management, it is expected that good results can be realized during the time of crisis.

\section{Reference}

A Comprehensive Guide on Mental Health \& Psychosocial Support During the Covid-19 Pandemic (2020). Ministry of Health, Kenya. Retrieved from https://www. health. go.ke/wp-content/uploads/2020/05/GUIDEON-MENTAL-HEALTH-AND-PSYCHOSOCIALSUPPORT-DURING-THE-COVID-19 PANDEMIC -compressed.pdf

Abdi, L. D. (2020, May 8). Kenyans Held for Weeks in Quarantine Were Told to Pay to Get Out Retrieved from https://www. nytimes.com /2020/05/08/world/ africa/kenya-coronavirus-quarantine.html

Crisis Group Africa. (28 October 2015). The Politics Behind the Ebola Crisis. Report $N^{\circ} 232$.

de Wilde, A.H., Snijder, E.J., Kikkert, M., \& van Hemert M.J. (2020). Host factors in coronavirus replication. PMC. Retrieved from

https://www.ncbi.nlm.nih.gov/pmc/articles/ PMC7119980/
Gathara P. (2020, May 7). Kenya is turning a public health crisis into a law-and-order one. Retrived from https://www.washingtonpost.com/opinions /2020/05/07/kenya-is-turning-publichealth-crisis-into-law-and-order-one/

Kenya National Bureau of Statistics. (2019). 2019 Kenya Population and Housing Census Results. Retrieved from https://www.knbs.or.ke/?p=5621

Lai, C-C., Shih, T-P., Ko, W-C., Tang, H-J., \& Hsueh, PR. (2020). Severe acute respiratory syndrome coronavirus 2 (SARS-CoV-2) and corona virus disease-2019 (COVID19): the epidemic and the challenges. Int J Antimicrob Agents 05924.

Nyamori M. (2020, April). How Sh1 billion coronavirus fund was spent. Retrieved from https://www.standardmedia.co.ke/health/ article/2001369631/how-sh1-billioncoronavirus-fund-was-spent

Paules $\mathrm{Cl}$, Marston HD, Fauci AS. Coronavirus Infections-More Than Just the Common Cold. JAMA. 2020;323(8):707-708. doi:10.1001/jama.2020.0757

Presidential Press Conference (2020). Retrived from https://www.president.go.ke/2020/03/15/a ddress-to-the-nation-by-h-e-uhuru-kenyatta -c-g-h-president-of-the-republic-of-kenyaand-commander-in-chief-of-the-defenceforces-on-covid-19-commonly-known-ascoronavirus/

Rashid, A. (2020). Press Conference held by Dr. Rashid Aman, the Chief Administrative Secretary (CAS) for Health Ministry, Kenya. Retrived from https://www.health.go.ke/ government- working-to-ensure-foodhandlers-are-tested-nairobi-april-28-2020/

Ruvagu L. (2020, September 18). Graft Alleged as Kenya's Fight Against COVID-19 Struggles. Retrivedfrom:https://www.voanews.com/c ovid-19-pandemic/graft-alleged-kenyasfight-against-covid-19-struggles.

Song, Z., Xu, Y., Bao, L., Zhang, L., Yu, P., Qu, Y., Zhu, H., Zhao, W., Han, Y. \& Qin, C. (2019). From SARS to MERS, thrusting coronaviruses into the spotlight. Viruses 
11(1):11. doi: $\quad 10.3390 / v 11010059$. Retrieved from https://pubmed. ncbi.nlm .nih.gov/30646565/

Statement-on-Confirmed-COVID-19-Case- (2020) Ministry of Health Kenya. Retrived from https://www.health.go.ke/wp-content/ uploads/2020/03/Statement-on-ConfirmedCOVID-19-Case-13-March-2020-final.pdf
Wang, Q., Qiu, Y., Li, JY. et al. (2020). A Unique Protease Cleavage Site Predicted in the Spike Protein of the Novel Pneumonia Coronavirus (2019-nCoV) Potentially Related to Viral Transmissibility. Virol. Sin. 35, 337339. https://doi.org/10.1007/s12250-02000212

Warren, B. \& Burt N. (1985). Leaders: The Strategies for Taking Change. New York: Harper and Row Printing Press. 